\title{
PENGARUH RELAKSASI RELIGIUS TERHADAP PENURUNAN TINGKAT INSOMNIA PADA LANSIA DI PSLU BONDOWOSO
}

\author{
Trisna Vitaliati \\ Program Studi Ners, STIKES dr. Soebandi Jember \\ Jalan dr. Soebandi 99 Jember 68111, Jawa Timur, Indonesia \\ *)E-mail : trisnavital7@gmail.com
}

Dikirim: Maret 2017, diterbitkan: April 2017

\begin{abstract}
ABSTRAK
Tujuan penelitian: Penelitian ini bertujuan untuk mengidenfikasi pengaruh relaksasi religius terhadap penurunan tingkat insomia di PSLU Bondowoso. Metode: Metode penelitian yang digunakan ialah quasi experimental dengan pendekatan pre-post test control group design menggunakan instrumen Insomnia Rating Scale, dilakukan pada kelompok intervensi $(n=31)$ dan kelompok kontrol $(n=31)$. Analisis data dilakukan secara univariat dan bivariat. Hasil: Hasil penelitian menunjukkan skor rerat a perubahan tingkat insomnia pada kelompok intervensi maupun kelompok kontrol. Pada hasil uji Mann Whitney didapatkan nilai p-value $=0,021$ sehingga dapat disimpulkan bahwa terapi relaksasi religius berpengaruh secara signifikan terhadap penurunan tingkat insomnia pada lansia. Diskusi: Relaksasi religius akan membuat seseorang merasa tenang sehingga kemudian menekan kerja saraf simpatis dan mengaktifkan kerja sistem saraf parasimpatis. Perlakuan relaksasi religius cukup efektif untuk memperpendek waktu dari mulai merebahkan tubuh hingga tertidur dan mudah memasuki tidur. Hal ini membuktikan bahwa relaksasi religius yang dilakukan dapat membuat lebih relaks sehingga kesulitan ketika mengawali tidur dapat diatasi dengan perlakuan ini. Kesimpulan: Teknik relaksasi religius efektif menurunkan tingkat insomnia pada lansia sehingga program ini disarankan dapat diterapkan pada lansia sebagai bagian dari program kesehatan lansia.
\end{abstract}

Kata Kunci: insomnia, lansia, relaksasi religius.

\section{EFFECT OF RELIGIUS RELAXATION ON DECREASING INSOMNIA LEVEL IN THE ELDERLY AT PSLU BONDOWOSO}

\section{ABSTRACT}

Objective: This study aims to identify the effect of religious relaxation on decreasing insomnia level at PSLU Bondowoso. Methods: This study was quasi-experimental with pre-posttest control group design using Insomnia Rating Scale and was conducted on intervention group $(n=31)$ and control group $(n=31)$. Data were analyzed using univariate and bivariate. Results: The results of the study indicated the average score of changes in insomnia levels in intervention group and control group. The results of Mann-Whitney test indicated $p$-value $=0.021$ so it could be concluded that religious relaxation therapy significantly affected the decrease in insomnia levels in the elderly. Discussion: Religious relaxation will make a person feel calm, which will then press the work of sympathetic nervous and activate the work of the parasympathetic nervous system. The treatment of religious relaxation is effective to shorten the time from lying down to falling asleep and easily entering into sleep. This proves that religious relaxation can make a person more relaxed so that difficulty when initiating sleep can be overcome by this treatment. Conclusion: Religious relaxation technique is effective in decreasing insomnia levels in the elderly so that this program is recommended to be applied in the elderly as a part of elderly health program. Keywords: insomnia, elderly, religious relaxation

\section{LATAR BELAKANG}

Insomnia didefinisikan sebagai suatu keluhan tentang kurangnya kualitas tidur yang disebabkan oleh satu dari beberapa faktor seperti sulit memasuki tidur, sering terbangun malam kemudian kesulitan untuk 
kembali tidur, bangun terlalu pagi, dan tidur yang tidak nyenyak (Mading, 2015). Insomnia merupakan salah satu gangguan utama dalam memulai dan mempertahankan tidur di kalangan lansia. Hal ini berhubungan dengan proses degenerasi pada lansia yang dapat mengakibatkan kuantitas tidur lansia akan semakin berkurang sehingga tidak tercapai tidur yang adekuat (Nugroho, 2008).

Penyembuhan terhadap insomnia tergantung dari penyebab yang menimbulkan insomnia. Bila penyebabnya kebiasaan yang salah atau lingkungan yang kurang kondusif untuk tidur, terapi yang dilakukan ialah mengubah kebiasaan dan lingkungannya. Sementara itu, bila penyebabnya psikologis, konseling dan terapi relaksasi dapat digunakan untuk mengurangi gangguan sulit tidur. Terapi ini merupakan bentuk terapi psikologis yang didasarkan pada teori-teori behavioris (Purwaningsih dan Isnaini, 2010). Banyak cara yang dapat digunakan untuk menanggulangi masalah tidur pada lansia secara nonfarmakologis di antaranya sleep restriction therapy, terapi pengontrolan stimulus, higiene tidur, teknik relaksasi, dan biofeedback (Ghaddafi, 2006).

Relaksasi religius ini merupakan pengembangan metode respons relaksasi dengan melibatkan faith factor dari Benson (Purwanto, 2007). Formula-formula tertentu yang dibaca berulang-ulang dengan melibatkan unsur keimanan kepada agama, kepada Tuhan yang disembah akan menimbulkan respons relaksasi yang lebih kuat yang dapat membantu seseorang mencapai kondisi kesehatan dan kesejahteraan yang lebih tinggi daripada sekedar relaksasi tanpa melibatkan unsur keyakinan terhadap hal tersebut (Aryana \& Novitasari, 2013). Relaksasi dicapai karena kombinasi dari respons fisiologis, psikologis, kognitif, dan sosial seseorang dengan teknik relaksasi (Songwathana \& Madriyono, 2009).
Salah satu faktor yang dapat memengaruhi kebutuhan tidur lansia ialah faktor agama/ kepercayaan seseorang. Usia lanjut memang merupakan masa ketika keadaan religius semakin diperkuat sehingga faktor keyakinan ini juga akan berpengaruh terhadap pelaksanaan teknik relaksasi (Anggrasari, 2013). Kesesuaian kebutuhan spiritual yang dibutuhkan dan ketenangan yang ditimbulkan dari terapi religius merupakan hal yang menciptakan perubahan kualitas tidur pada lansia sehingga dapat mengurangi insomnia (Purwanto, 2016).

Berdasarkan studi pendahuluan di Unit Pelaksana Teknik Panti Sosial Lanjut Usia (UPT PSLU) Bondowoso, terdapat 90 lansia. Pada hasil wawancara dengan lansia tentang gangguan tidur atau insomnia didapatkan 72 lansia mengalami insomnia. Lansia yang menderita gangguan tidur mengatakan hal tersebut disebabkan oleh beberapa faktor, yaitu faktor penyakit yang diderita, seperti asam urat, hipertensi, vertigo, asma, serta lingkungan yang kurang kondusif atau tempat tidur yang kurang bersih. Tindakan yang dilakukan sendiri oleh lansia di PSLU ialah sekitar $40 \%$ lansia melakukan jalanjalan berkeliling PSLU, 20\% mendengarkan radio, 10\% menyanyikan lagu tradisional, dan $30 \%$ menonton televisi jika tidak bisa tidur dengan nyaman. Berdasarkan hal tersebut, penulis tertarik untuk melakukan penelitian berjudul "Pengaruh Teknik Relaksasi Religius terhadap Perubahan Tingkat Insomnia pada Lansia di PSLU Bondowoso".

\section{METODE}

Penelitian ini merupakan jenis penelitian kuantitatif dengan menggunakan desain "quasi experimental pre-post test with control group" dengan intervensi terapi relaksasi religius. Penelitian ini membandingkan dua kelompok lansia yang mengalami insomnia di PSLU Bondowoso, yaitu kelompok intervensi 
(kelompok yang diberikan terapi relaksasi religius) dan kelompok kontrol (kelompok yang diberikan terapi relaksasi napas dalam). Penetapan sampel dalam penelitian ini menggunakan teknik purposive sampling, yaitu peneliti memiliki pertimbangan tertentu dalam memilih partisipan yang terlibat dalam penelitian (Polit dan Hungler, 1999), didapatkan 62 responden, kemudian diundi secara acak dan diklasifikasikan menjadi 31 orang masuk kelompok intervensi dan 31 orang masuk kelompok kontrol. Data dikumpulkan dengan kuesioner dalam bentuk Insomnia Rating Scale yang dikembangkan oleh Kelompok Studi Psikiatri Biologi Jakarta (KSPBJ) yang dimodifikasi sesuai dengan kondisi lansia (Prasetya, 2016).

Penelitian ini dilaksanakan sesuai prosedur penelitian yakni sebelumnya peneliti memberikan informasi yang benar dan jelas mengenai tujuan, manfaat, dan prosedur penelitian. Selain itu, peneliti juga memberikan inform concent kepada responden sebelum penelitian dilakukan dengan memberikan lembar persetujuan menjadi responden.
Responden kelompok kontrol diberikan perlakuan relaksasi napas dalam, yaitu dengan napas lambat dan menghembuskan napas secara perlahan. Sementara itu, untuk kelompok intervensi dilakukan terapi relaksasi religius yang merupakan gabungan relaksasi napas dalam dengan penyebutan "Allah" secara berulang-ulang, berdoa yang disertai dengan sikap pasrah, masingmasing dilakukan selama 25-30 menit selama 1 bulan (Songwathana \& Madriyono, 2009). Kemudian, dilakukan post-test baik pada kelompok kontrol maupun kelompok intervensi.

Analisis data dilakukan secara univariat dan bivariat. Karena data hasil penelitian tidak berdistribusi normal, untuk melihat perbedaan tingkat insomnia lansia sebelum dan sesudah diberikan perlakuan pada kelompok kontrol dan kelompok intervensi, data dianalisis dengan menggunakan Wilcoxon Signed Ranks Test. Sementara itu, untuk melihat perbedaan tingkat insomnia antara kelompok kontrol dan kelompok intervensi setelah diberikan perlakukan dianalisis menggunakan uji Mann Whitney.

\section{HASIL}

Berdasarkan hasil penelitian data demografi yang diamati pada responden didapatkan data sebagai berikut.

Tabel 1. Distribusi frequensi data demografi responden di UPT PSLU Bondowoso $(n=62)$

\begin{tabular}{cccccc}
\hline Variabel & \multicolumn{2}{c}{ Intervensi } & \multicolumn{2}{c}{ Kontrol } & \multirow{2}{*}{ p-value } \\
\cline { 2 - 5 } & $\mathbf{F}$ & $\%$ & $\mathbf{F}$ & $\%$ & \\
\hline Usia & & & & & \\
60-69 Tahun & 12 & $19,4 \%$ & 12 & $19,4 \%$ & \\
70-79 Tahun & 12 & $19,4 \%$ & 17 & $27,4 \%$ & 0,697 \\
280 Tahun & 7 & $11,3 \%$ & 2 & $3,2 \%$ & \\
Jenis Kelamin & & & & & \\
Laki-laki & 13 & $21 \%$ & 16 & $25,8 \%$ & \\
Perempuan & 18 & $29 \%$ & 15 & $24,2 \%$ & 0,356 \\
Pendidikan & & & & & \\
Tidak sekolah & 13 & $21 \%$ & 12 & $19,4 \%$ & \\
SD & 9 & $14,5 \%$ & 9 & $14,5 \%$ & 0,546 \\
SMP & 4 & $6,5 \%$ & 5 & $8,1 \%$ & \\
SMA & 2 & $3,2 \%$ & 4 & $6,5 \%$ & \\
Sarjana & 3 & $4,8 \%$ & 1 & $1,6 \%$ & \\
\hline
\end{tabular}


Hasil analisis distribusi responden berdasarkan usia, jenis kelamin, dan pendidikan menunjukkan bahwa sebagian besar responden berusia 70-79 tahun sebanyak $46,8 \%$ dan berjenis kelamin perempuan $53,2 \%$ dengan tingkat pendidikan paling banyak adalah tidak sekolah $40,3 \%$.
Berdasarkan Tabel 1 didapatkan bahwa tidak ada perbedaan yang bermakna pada karakteristik usia, jenis kelamin dan tingkat pendidikan ( $p$-value $>0,05)$. Hal ini menunjukkan bahwa karakteristik responden pada kelompok kontrol maupun kelompok intervensi homogen.

Tabel 2. Distribusi responden berdasarkan tingkat insomnia sebelum dan setelah diberikan perlakukan pada lansia di UPT PSLU Bondowoso

\begin{tabular}{ccccccccc}
\hline & \multicolumn{3}{c}{ Kelompok Intervensi } & \multicolumn{3}{c}{ Kelompok Kontrol } \\
\cline { 2 - 9 } & \multicolumn{2}{c}{ Sebelum } & \multicolumn{2}{c}{ Sesudah } & \multicolumn{2}{c}{ Sebelum } & \multicolumn{2}{c}{ Sesudah } \\
\cline { 2 - 9 } & $\mathbf{F}$ & $\%$ & $\mathbf{F}$ & $\%$ & $\mathbf{F}$ & $\%$ & $\mathbf{F}$ & $\%$ \\
\hline Insomnia ringan & 14 & $45,2 \%$ & 18 & $58,1 \%$ & 19 & $61,3 \%$ & 18 & $58,1 \%$ \\
Insomnia sedang & 17 & $54,8 \%$ & 1 & $3,2 \%$ & 12 & $38,7 \%$ & 12 & $38,7 \%$ \\
Tidak insomnia & 0 & $0 \%$ & 12 & $38,7 \%$ & 0 & $0 \%$ & 1 & $3,2 \%$ \\
\hline
\end{tabular}

Tabel 2 menunjukkan tingkat insomnia pada lansia sebelum dan setelah dilakukan intervensi terapi relaksasi religius. Pada data yang disajikan terlihat bahwa terjadi perubahan tingkat insomnia pada lansia dari $100 \%$ mengalami insomnia, baik sedang maupun ringan menjadi 38,7\% tidak insomnia. Sementara itu, pada kelompok kontrol dapat diketahui bahwa ada perbedaan tingkat insomnia pada lansia sebelum dan setelah dilakukan intervensi relaksasi napas dalam, dapat terlihat perubahan tingkat insomnia pada lansia meskipun hanya sedikit mengalami penurunan.

Tabel 3. Perbedaan tingkat insomnia pada lansia sebelum dan sesudah diberikan intervensi antara kelompok intervensi dan kelompok kontrol $(n=62)$

\begin{tabular}{l|c|c}
\hline \multicolumn{1}{c}{ Variabel } & Kelompok & p-value \\
\hline Tingkat & Intervensi & $0,000^{\mathrm{a}}$ \\
Insomnia & Kontrol & $0,001^{\mathrm{a}}$ \\
\hline
\end{tabular}

Keterangan: a) menggunakan Wilcoxon Signed Ranks Test Signifikan jika p-value $<0,05$

Berdasarkan uji statistik dengan bahwa terdapat perbedaan yang bermakna menggunakan uji Wilcoxon pada kelompok pada tingkat insomnia lansia antara sebelum intervensi maupun kelompok kontrol diperoleh dan sesudah dilakukan intervensi.

nilai $p$-value $<0,05$. Hal ini menunjukkan

Tabel 4. Perbedaan indikator tingkat insomnia pada lansia setelah intervensi antara kelompok intervensi dan kelompok kontrol $(n=62)$

\begin{tabular}{l|r|r|r}
\hline Variabel & \multicolumn{2}{|c}{ Mean } & p-value \\
& $\begin{array}{r}\text { Kelompok } \\
\text { Intervensi }\end{array}$ & $\begin{array}{r}\text { Kelompok } \\
\text { Kontrol }\end{array}$ & \\
\hline $\begin{array}{l}\text { Ting ka t } \\
\text { Insomnia }\end{array}$ & 26,31 & 36,69 & $0,021^{\mathrm{a}}$ \\
\hline
\end{tabular}

Keterangan: a) menggunakan uji Mann Whitney Signifikan jika p-value $<0,05$ 
Berdasarkan hasil uji Mann Whitney dapat diketahui bahwa setelah dilakukan intervensi terapi, baik pada kelompok intervensi maupun pada kelompok kontrol menunjukkan adanya perbedaan yang signifikan ( $p$-value=0,021). Dengan demikian, dapat disimpulkan bahwa intervensi relaksasi religius maupun relaksasi napas dalam memiliki pengaruh terhadap penurunan tingkat insomnia pada lansia.

\section{DISKUSI}

Hasil penelitian menunjukkan bahwa setelah diberi perlakuan relaksasi religius, terdapat penurunan tingkat insomnia pada lansia diketahui 12 orang tidak insomnia, 18 orang insomnia sedang, dan 1 orang insomnia sedang. Terapi relaksasi religius dapat membangkitkan relaxation response (RR). Respons relaksasi ini merupakan mekanisme respons yang protektif terhadap otak dan teknik ini dilakukan selama 25-30 menit (Songwathana \& Madriyono, 2009).

Jenis kelamin perempuan paling banyak yang menderita insomnia. Hal ini bisa disebabkan perempuan mengalami perubahan hormon dan tingkat stres yang tinggi (Hapsari, 2014). Ketika seseorang mengalami stres, beberapa otot akan mengalami ketegangan yang dapat menyebabkan terjadinya insomnia. Aktifnya saraf simpatis tersebut membuat orang tidak dapat santai atau rileks sehingga tidak dapat memunculkan rasa kantuk.

Melalui relaksasi religius, subjek dilatih untuk dapat memunculkan relaksasi sehingga dapat mencapai keadaan tenang. Respons relaksasi ini terjadi penurunan bermakna dari kebutuhan zat oksigen oleh tubuh, aliran darah perifer akan lancar, neurotransmiter penenang akan dilepaskan, dan sistem saraf akan bekerja secara baik, selanjutnya otototot tubuh yang rileks menimbulkan perasaan tenang dan nyaman yang pada akhirnya akan menurunkan tingkat insomnia pada lansia (Al-Halaj, 2014). Relaksasi religius akan membuat seseorang merasa tenang sehingga kemudian menekan kerja saraf simpatis dan mengaktifkan kerja sistem saraf parasimpatis (Maimunah \& Retnowati, 2011).

Berdasarkan hasil penelitian, 31 responden yang mengalami insomnia dengan tingkat yang berbeda, setelah diberi perlakuan terapi napas dalam sebanyak 1 orang $(3,2 \%)$ tidak mengalami insomnia. Hal tersebut membuktikan bahwa terapi relaksasi nafas dalam dapat menurunkan tingkat insomnia pada lansia. Hasil penelitian ini sesuai dengan penelitian Sarmini (2012) yang menyatakan bahwa teknik relaksasi nafas dalam mampu menurunkan kecemasan pada lansia.

Hasil penelitian ini menunjukkan bahwa terapi relaksasi religius dan relaksasi nafas dalam dapat menurunkan tingkat insomnia pada lansia meskipun pada nafas dalam tingkat penurunannya hanya sedikit, akan tetapi keduanya sama-sama mampu membuat penderita insomnia menjadi rileks. Dengan kata lain keadaan relaksasi akan menimbulkan dampak psikis yang lebih tenang dan rileks (Darmawanti, 2012).

Pelatihan relaksasi religius cukup efektif untuk memperpendek waktu dari mulai merebahkan hingga tertidur dan mudah memasuki tidur. Hal ini membuktikan bahwa relaksasi religius yang dilakukan dapat membuat lebih relaks sehingga keadaan kesulitan ketika mengawali tidur dapat diatasi dengan treatmen ini. Kemudahan dalam mengawali tidur ini juga akan berdampak pada lama tidur, dengan tidur lebih awal dari biasanya dan masa memasuki tidur lebih pendek secara langsung akan memperlama jam tidur subjek (Purwanto, 2007). Lama tidur bukanlah ukuran standar seseorang harus tidur 8 jam atau tidak, tetapi bagi penderita insomnia, peningkatan lama tidur cukup berarti. Mudahnya tidur dan 
berkurangnya lama waktu memasuki tidur dapat mengurangi stres tentang kebiasaan mengawali tidur. Stress akibat tidak bisa tidur bisa menjadi ketegangan sendiri yang sering kali menyebabkan semakin tidak bisa tidur. Keterbatasan penelitian ini ialah peneliti tidak dapat mengontrol antar kelompok intervensi dan kelompok kontol karena jarak tempat tidur lansia berdekatan dan tidak dapat mencegah komunikasi antara kedua kelompok tersebut.

\section{SIMPULAN}

Hasil penelitian menunjukkan ada perbedaan tingkat insomnia sebelum dan sesudah dilakukan intervensi baik pada kelompok kontrol maupun kelompok intervensi. Dari hasil uji statistik MannWhitney diperoleh nilai $P$ value $0,021<\alpha 0,05$. Dengan demikian, dapat disimpilkan bahwa terdapat pengaruh relaksasi religius terhadap penurunan tingkat insomnia pada lansia.

Diharapkan dengan adanya penelitian ini, pihak Dinas Sosial menggunakan terapi relaksasi religius dalam mengatasi insomnia pada lansia. Terapi ini diketahui tidak memiliki efek samping lain bagi lansia selain dapat menimbulkan ketenangan. Lebih lanjut, diharapkan adanya penelitian dengan variabel yang lain dalam mengatasi kesehatan lansia.

\section{DAFTAR PUSTAKA}

Al-Halaj, Q. M. (2014). Pengaruh dzikir menjelang tidur terhadap kualitas tidur usia di Panti Sosial Tresna Wredha Budi Mulia 01 Jakarta Timur (Skripsi). Program Studi IImu Keperawatan Fakultas Kedokteran dan IImu Kesehatan, Universitas Islam Negeri Syarif Hidayatullah, Jakarta, Indonesia.

Anggrasari, A. P. (2013). Pengaruh teknik relaksasi Benson terhadap pemenuhan kebutuhan tidur pada lansia di Panti Wredha Hargo Dedali Surabaya. Jurnal Kesehatan Samodra IImu, 4,(2): 73-83.
Aryana, K. O \& Novitasari, D. (2013). Pengaruh teknik relaksasi Benson terhdap penurunan tingkat stress lansia di Unit Rehabilitasi Sosial Wening Wardoyo Ungaran. Jurnal Keperawatan Jiwa, 1(2): 186-195.

Darmawanti, I. (2012). Hubungan antara tingkat religiusitas dengan kemampuan dalam mengatasi stress. Jurnal Psikologi: Teori dan Terapan, 2(2): 24-29.

Ghaddafi, M. (2013). tatalaksana insomnia dengan farmakologi atau non farmakologi. E-jurnal Medika Udayana, 2(11)

Hapsari, N. E. (2014. Pengaruh diaphragmatic breathing exercise terhadap penurunan insomnia pada lansia wanita (Skripsi). Fakultas IImu Kesehatan Universitas Muhammadiyah, Surakarta, Jawa Tengah, Indonesia.

Mading, F. (2015). Gambaran karakteristik lanjut usia yang mengalami insomnia di Panti Wreda Dharma Bakti Pajang Surakarta (Skripsi). Universitas Muhammadiyah Surakarta, Surakarta, Indonesia.

Maimunah, A. \& Retnowati, S. (2011). Pengaruh pelatihan relaksasi dengan dzikir untuk mengatasi kecemasan ibu hamil pertama". Psikoislamika, Jurnal Psikologi Islam, 8(1): 1-22.

Nugroho, W. (2008). Keperawatan Gerontik dan geriatrik. Jakarta: Penerbit buku kedokteran EGC.

Polit, D. F. \& Hungler, B. P. (1999). Nursing research: Principle and methods, $6^{\text {th }}$ edition. Philadhelphia: Lippincot Williams and Wilkins.

Prasetya, Z. (2016). Pengaruh terapi relaksasi otot progresif terhadap perubahan tingkat insomnia pada lansia (skripsi). Fakultas Kedokteran dan IImu Kesehatan Universitas Islam Negeri Alauddin Makassar, Sulawesi Selatan, 
Indonesia

Purwaningsih, Y. \& Isnaini, Y. 2010. Pengaruh terapi wudlu sebelum tidur terhadap kejadian insomnia jangka pendek pada lanjut usia di PSTW Budhi Dharma Ponggalan Yogyakarta (Skripsi). Prodi IImu Keperawatan STIKES Aisyiyah, Yogyakarta, Indonesia.

Purwanto, S. (2007). Pengaruh latihan relaksasi religius untuk mengurangi gangguan insomnia (Tesis). Universitas Gadjah Mada, Yogyakarta, Indonesia.

Sarmini. (2012). Perbedaan tingkat kecemasan pada lansia sebelum dan sesudah diberikan teknik relaksasi nafas dalam di Panti Wreda Dharma Bhakti Surakarta (Skripsi). Fakultas IImu Kesehatan Universitas Muhammadiyah Surakarta, Surakarta, Indonesia.

Songwathana, P \& Madriyono. (2009). Islamic relaxation outcomes: A literature review. The Malaysian Journal of Nursing, 26-30. 